\title{
Phylogenetic diversity in the genus Bacillus and comparative ribosomal protein AT-L30 analyses of the genus Thermoactinomyces and relatives
}

\author{
Kozo Ochi
}

Tel: +8129838 8125. Fax: +81298387996.

National Food Research Institute, 2-1-2 Kannondai, Tsukuba, Ibaraki 305, Japan

\begin{abstract}
The ribosomal L30 proteins from strains of 27 species belonging to the genera Bacillus, Escherichia, Staphylococcus, Lactobacillus, Leuconostoc and Thermoactinomyces were analysed, together with AT-L30 proteins from selected actinomycetes. The results of partial amino acid sequencing of L30 preparations revealed that the members of the genera Escherichia, Staphylococcus and Thermoactinomyces were homogeneous within each genus. In contrast, phylogenetic diversity existed in the genus Bacillus, which contained at least four clusters. One cluster that contained Bacillus subtilis and Bacillus stearothermophilus was more closely related to the genus Staphylococcus than to members of the other three Bacillus clusters. Members of the genus Thermoactinomyces were most closely related to the 'Bacillus subtilis cluster', but less related to the other three Bacillus clusters. A distant phylogenetic relationship was detected between the genus Thermoactinomyces and its morphological relative, Thermomonospora.
\end{abstract}

Keywords: Bacillus, Thermoactinomyces, ribosomal protein AT-L30, amino acid sequencing

\section{INTRODUCTION}

It has been recognized that Bacillus is a very diverse genus, as indicated by the enormous range of genomic guanineplus-cytosine $(\mathrm{G}+\mathrm{C})$ contents $(32-69 \mathrm{~mol} \%$ : Priest, 1981; Claus \& Berkeley, 1986) and by the variety of phenotypes (Gordon, 1981; Logan \& Berkeley, 1981). Moreover, recent phylogenetic investigations by $16 \mathrm{~S}$ rRNA sequencing have shown the heterogeneity of Bacillus at the genus level. Based on the data set of $16 \mathrm{~S}$ rRNA sequences Rössler et al. (1991) divided nine Bacillus species into four clusters. Similarly, Ash et al. (1991) and Farrow et al. (1992) recognized that over 50 species of Bacillus examined form five phylogenetically distinct clusters on the basis of 16S rRNA sequence data. The phylogenetic incoherency of Bacillus has also been shown by Stackebrandt et al. (1987) and Wisotzkey et al. (1992). At present 40 Bacillus species are listed in Bergey's Manual of Systematic Bacteriology (Claus \& Berkeley, 1986). It is evident that the Bacillus species should be subjected to further phylogenetic investigation for the systematic reclassification of this genus.

\footnotetext{
Abbreviations: REM, relative electrophoretic mobility; SAS, similarity of
} amino acid sequences.
The genus Thermoactinomyces contains thermophilic bacteria which form endospores like those of the genus Bacillus. It contains seven species in Bergey's Manual of Systematic Bacteriology (Lacey \& Cross, 1989) and occupies a unique position in bacterial taxonomy. Until recently, it was considered to be an actinomycete, mainly because of its ability to form aerial mycelium when cultured on solid media. However, chemotaxonomic studies have cast doubts on the status of the members of the genus Thermoactinomyces as true actinomycetes: their wall peptidoglycan contains meso-diaminopimelic acid but no diagnostic sugars (wall chemotype III) (Becker et al., 1965); their menaquinones are unsaturated with seven or nine isoprene units (Collins et al., 1982); and spores are formed as endospores and contain dipicolinic acid (Cross et al., 1971; Lacey, 1971). These characters are all shared with the genera Bacillus and Clostridium but not Streptomyces, a representative actinomycete genus (reviewed by Lacey \& Cross, 1989). Moreover, the DNA base composition of Thermoactinomyces species has a G +C content $(52-55 \mathrm{~mol} \%)$ lower than that found in other actinomycete genera (about $70 \mathrm{~mol} \%$ ) but similar to that of Bacillus species (32-69 mol \%) (Craveri \& Manachini, 1966; Fritzsche, 1967). Recent phylogenetic investigations have supported the above concept and 16S rRNA data (Stackebrandt \& Woese, 1981; Stackebrandt et al., 
Table 1. Strains used in this study

\begin{tabular}{|c|c|c|}
\hline Species & Strain designation* & $\begin{array}{c}\text { Species abbreviation } \\
\text { used in this paper }\end{array}$ \\
\hline Bacillus alvei & $\operatorname{ATCC} 6344^{\mathrm{T}}$ & Bal \\
\hline Bacillus brevis & $\mathrm{JCM} 2503^{\mathbf{T}}\left(=\mathrm{ATCC} 8246^{\mathrm{T}}\right)$ & $\mathrm{Bbr}$ \\
\hline Bacillus cereus & JCM $2152^{\mathrm{T}}\left(=\right.$ ATCC $\left.14579^{\mathrm{T}}\right)$ & Bce \\
\hline Bacillus cyclobeptanicus & ATCC $49028^{\mathrm{T}}$ & Bcy \\
\hline Bacillus laterosporus & JCM $2496^{\mathrm{T}}\left(=\mathrm{ATCC} 8248^{\mathrm{T}}\right)$ & $\mathrm{Bla}$ \\
\hline Bacillus macerans & JCM $2500^{\mathrm{T}}\left(=\right.$ ATCC $\left.8244^{\mathrm{T}}\right)$ & Bma \\
\hline Bacillus macquariensis & ATCC $23464^{\mathrm{T}}$ & $\mathrm{Bmq}$ \\
\hline Bacillus megaterium & JCM $2506^{\mathrm{T}}\left(=\right.$ ATCC $\left.14581^{\mathrm{T}}\right)$ & Bme \\
\hline Bacillus polymyxa & JCM $2507^{\mathrm{T}}\left(=\operatorname{ATCC~} 842^{\mathrm{T}}\right)$ & Bpo \\
\hline Bacillus stearothermopbilus & NCA 1503 & Bst \\
\hline Bacillus subtilis & $\mathrm{JCM} 1465^{\mathrm{T}}\left(=\mathrm{ATCC} 6051^{\mathrm{T}}\right)$ & Bsu \\
\hline Bacillus subtilis & Marburg & Bsu \\
\hline Escherichia coli & $\mathrm{K} 12$ & Eco \\
\hline Escherichia fergusonii & JCM $5897(=$ ATCC 35471) & Efe \\
\hline Escherichia bermannii & $\mathrm{JCM} 1473^{\mathrm{T}}\left(=\operatorname{ATCC} 33650^{\mathrm{T}}\right)$ & Ehe \\
\hline Eschericbia vulneris & JCM $1688^{\mathrm{T}}\left(=\operatorname{ATCC} 33821^{\mathrm{T}}\right)$ & Evu \\
\hline Lactobacillus plantarum & JCM $1149^{\mathrm{T}}\left(=\right.$ ATCC $\left.14917^{\mathrm{T}}\right)$ & Lpl \\
\hline $\begin{array}{l}\text { Leuconostoc mesenteroides } \\
\text { subsp. mesenteroides }\end{array}$ & JCM $6124^{\mathrm{T}}\left(=\operatorname{ATCC} 8293^{\mathrm{T}}\right)$ & Lme \\
\hline Nocardia asteroides & JCM $3384^{\mathrm{T}}\left(=\right.$ ATCC $\left.19247^{\mathrm{T}}\right)$ & Nas \\
\hline Staphylococcus aureus & JCM 2151 (= ATCC 6538P) & Sau \\
\hline Staphylococcus aureus & $209 \mathrm{P}$ & Sau \\
\hline Staphylococcus epidermidis & JCM $2414^{\mathrm{T}}\left(=\right.$ ATCC $\left.14990^{\mathrm{T}}\right)$ & Sep \\
\hline Staphylococcus byicus subsp. byicus & JCM $2423^{\mathrm{T}}\left(=\right.$ ATCC $\left.11249^{\mathrm{T}}\right)$ & Shy \\
\hline Staphylococcus xylosus & JCM $2418^{\mathrm{T}}\left(=\right.$ ATCC $\left.29971^{\mathrm{T}}\right)$ & Sxy \\
\hline Streptomyces parvulus & ATCC $12434^{\mathrm{T}}$ & Spa \\
\hline Thermoactinomyces intermedius & $\mathrm{JCM} 3312^{\mathrm{T}}\left(=\operatorname{ATCC} 33205^{\mathrm{T}}\right)$ & Tin \\
\hline Thermoactinomyces sacchari & $\operatorname{JCM} 3137^{\mathrm{T}}\left(=\operatorname{ATCC} 27375^{\mathrm{T}}\right)$ & Tsa \\
\hline Thermoactinomyces thalpophilus & $\mathrm{JCM} 3217^{\mathrm{T}}$ & Tth \\
\hline Thermoactinomyces vulgaris & $\mathrm{JCM} 3162^{\mathrm{T}}$ & Tvu \\
\hline Thermomonospora cbromogena & $\mathrm{JCM} 62.44^{\mathrm{T}}$ & Tch \\
\hline Thermomonospora curvata & JCM $3096^{\mathrm{T}}\left(=\right.$ ATCC $\left.19995^{\mathrm{T}}\right)$ & Tcu \\
\hline Thermomonospora mesophila & JCM $3151^{\mathrm{T}}\left(=\right.$ ATCC $\left.27303^{\mathrm{T}}\right)$ & Tme \\
\hline
\end{tabular}

* $\mathrm{T}$, type strain.

1987) have established that the genus Thermoactinomyces is within the bacillus group and not the actinomycete group.

Ribosomes and their components have provided an excellent means of studying the evolution of organisms, since they are essential components for all cells. In addition to rRNA sequencing, ribosomal protein sequencing has also proved a useful approach, as demonstrated for members of the archaeobacteria (WittmannLiebold et al., 1990). During the last few years I have developed a novel method for the identification and classification of actinomycetes which depends on the heterogeneity of the ribosomal AT-L30 proteins among actinomycete genera (Ochi, 1989, 1992a, b). Analysis of the AT-L30 proteins by two-dimensional PAGE or by Nterminal amino acid sequencing has been used successfully to review the taxonomic status of various actinomycete genera (Ochi \& Yoshida, 1992; Ochi \& Miyadoh, 1992; Ochi et al., 1991, 1993a, b; Ochi \& Hiranuma, 1994). The extent of amino acid sequence homology among AT-L30 proteins has been a useful standard for classification at the genus level. The aim of the present study was to review the taxonomic status of the genera Bacillus and Thermoactinomyces by analysing the amino acid sequence of their L30 proteins.

\section{METHODS}

Bacterial strains. Almost all the strains used in this study were type strains (Table 1) that were obtained from the Japan Collection of Micro-organisms, Wako-shi, Saitama, Japan, and the American Type Culture Collection, Rockville, MD, USA. Although Bacillus cyclobeptanicus is currently assigned to the genus Alicyclobacillus (Wisotzkey et al., 1992), the earlier name has been used for convenience in this study. The strains were grown to mid-exponential phase in soluble starch/ polypeptone/yeast extract medium at $30^{\circ} \mathrm{C}$ (for actinomycetes) or $20-55^{\circ} \mathrm{C}$ (for other eubacteria).

Two-dimensional PAGE. Two-dimensional PAGE by the 
method of Kaltschmidt \& Wittmann (1970) has been described in detail previously (Ochi, 1989). The L30 or AT-L30 protein spot was identified after each slab gel had been stained with Coomassie blue. The electrophoretic mobilities (in the first dimension) of the L30 or AT-L30 proteins were expressed as relative electrophoretic mobilities (REMs) compared with the electrophoretic mobility of Saccharomonospora viridis AT-L30 protein, which exhibited the greatest mobility of all of the actinomycete AT-L30 proteins examined (Ochi, 1992a).

Determination of amino acid sequence. Amino acid sequence analysis of each L30 or AT-L,30 protein was carried out as described in detail by Ochi \& Miyadoh (1992), using a model $470 \mathrm{~A}$ protein sequencer (Applied Biosystems). The method is based upon the Edman degradation, and determination of a maximum of $27 \mathrm{~N}$-terminal amino acids was possible when about 100 pmol of L30 preparation was sampled. In Escherichia coli the L30 protein that corresponds to the actinomycete ATL30 proteins consists of 58 amino acid residues. The $27 \mathrm{~N}$ terminal amino acids, therefore, represent nearly half of the ATL30 protein, assuming that the $\mathrm{L} 30$ protein from E. coli and the AT-L 30 protein from actinomycetes are of the same size.

\section{RESULTS}

\section{Two-dimensional PAGE analysis of ribosomal proteins}

The ribosomal proteins of 27 species of the Gram-positive or -negative bacteria (Table 1) were extracted with acetic acid and separated by two-dimensional PAGE. The electrophoretic mobilities of the proteins assigned as L30 proteins in the first dimension of gel electrophoresis were similar for the species of the genera Eschericbia, Bacillus, Staphylococcus, Lactobacillus and Leuconostoc (REMs 68-76). Similar REM values (65-73) were detected for the four Thermoactinomyces species examined. Thus, eubacteria, including the genus Thermoactinomyces, appear to have a constant REM value of about 70 . These results contrast with a previous observation that among the genera of actinomycetes there exists a considerable electrophoretic heterogeneity of ribosomal AT-I.30 proteins (Ochi, $1992 \mathrm{a}, \mathrm{b})$. The experimental error for the REMs was $\leqslant 5 \%$, as determined from several gel runs of the same sample. To obtain further insight into the phylogenetic relationship we next conducted an amino acid sequence analysis of the L30 or AT-L30 proteins.

\section{Amino acid sequences of L30 or AT-L30 proteins (1) Genera Escherichia and Staphylococcus}

We first analysed L 30 proteins from four species each of the genera Staphylococcus and Escherichia, which were taken as representatives of Gram-positive and -negative bacteria, respectively (Fig. 1). To express quantitatively the levels of similarity of the amino acid sequences (SAS values), we determined the frequency of appearance of the same amino acid in $20 \mathrm{~N}$-terminal amino acids of each L30 protein for every combination of strains tested (Table 2).

Staphylococcus epidermidis and Staphylococcus xylosus, isolated from human skin, are validly described by Schleifer \& Kloos (1975) as new species in the genus Stapbylococcus. The former strain, together with $S$. aureus, has been subjected to 5S rRNA sequence analysis (Dekio et al., 1984). Staphylococcus byicus was validly published by Devriese et al. (1978). As shown in Fig. 1 and Table 2, these four species revealed a high level of amino acid sequence homology ( $\mathrm{SAS} \geqslant 94 \%$ ) for every combination of strains. Complete homology was detected between $S$. aureus, S. epidermidis and S. xylosus.

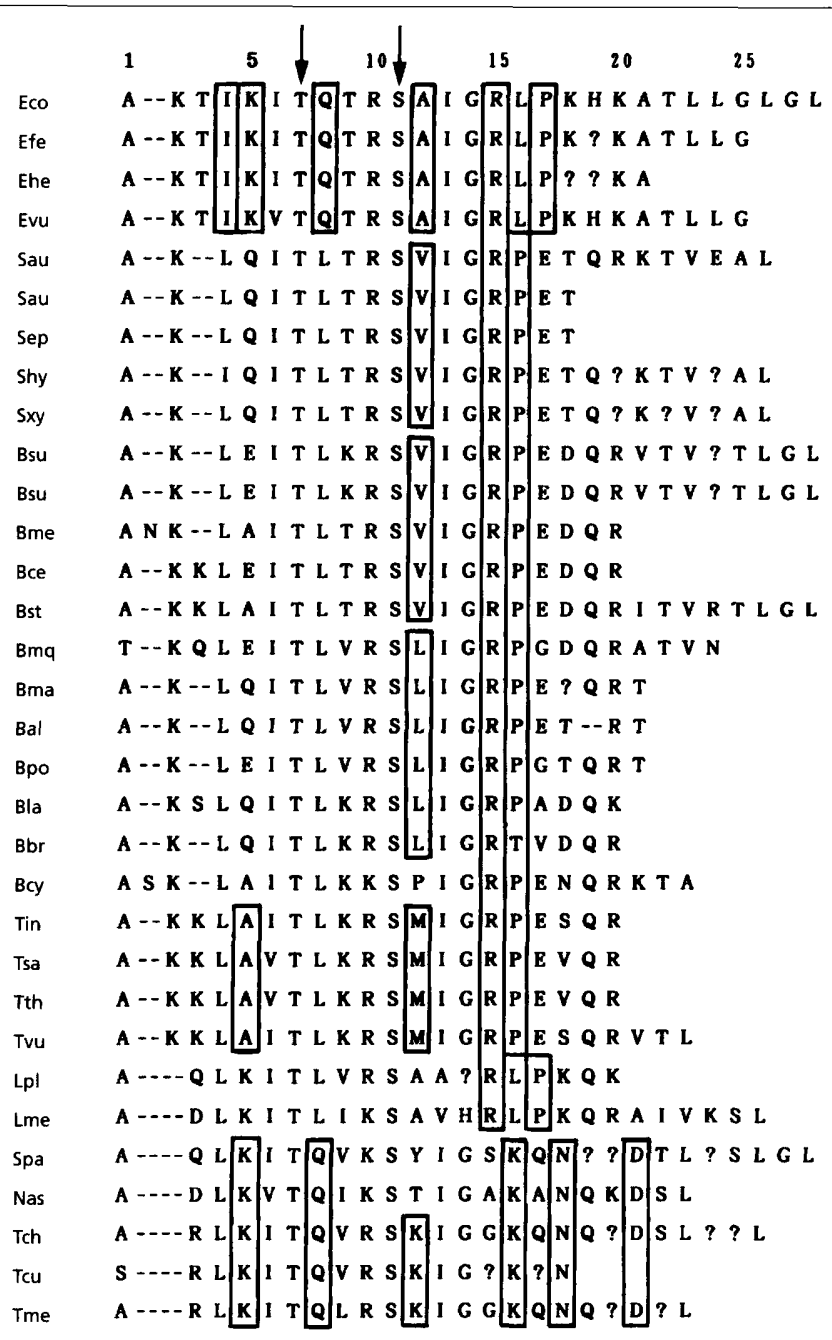

Fig. 1. Primary structures of $\mathrm{N}$-termini of the $\mathrm{L} 30$ or $A T-L 30$ proteins from eubacteria or actinomycetes. The abbreviation used for each organism is presented in Table 1. The amino acid numbering is given above the sequence of $E$. coli. Question marks indicate amino acids that were not determined. The dotted lines indicate deletions. The common sequence found in all strains or in a specified genus is indicated by an arrow or box, respectively. Sau (upper line), Staphylococcus aureus JCM 2151; Sau (lower line), Staphylococcus aureus 209P; Bsu (upper line), Bacillus subtilis JCM 1465'; Bsu (lower line), Bacillus subtilis Marburg. The data for Escherichia coli $\mathrm{K} 12$ and Bacillus stearothermophilus NCA 1503 are from Ritter \& WittmannLiebold (1975) and Kimura (1984), respectively. JP accession numbers are as follows: Efe (JP0042), Ehe (JP0043), Evu (JP0044), Sau (JP0045), Sep (JP0046), Shy (JP0047), Sxy (JP0048), Bsu (JP0049), Bme (JP0050), Bce (JP0051), Bmq (JP0052), Bma (JP0053), Bal (JP0054), Bpo (JP0055), Bla (JP0056), Bbr (JP0057), Bcy (JP0058), Tin (JP0059), Tsa (JP0060), Tth (JP0061), Tvu (JP0062), Lpl (JP0063), Lme (JP0064), Spa (JP0065), Nas (JP0066), Tch (JP0067), Tcu (JP0068), Tme (JP0069). 
Table 2. SAS values for the amino acid sequences of $L 30$ or AT-L30 proteins

The SAS values for each pair of organisms for $20 \mathrm{~N}$-terminal amino acids of the L30 or AT-L30 proteins was determined on the basis of the data shown in Fig. 1. Non-determined positions were not weighted for the calculation of SAS values. The abbreviations used for each organism are presented in Table 1.

\begin{tabular}{|c|c|c|c|c|c|c|c|c|c|c|c|c|c|c|c|c|c|c|c|c|c|c|}
\hline \multirow[t]{2}{*}{ Species } & \multicolumn{22}{|c|}{ SAS values $(\%)$} \\
\hline & Eco & Evu & Sau & Shy & Bsu & Bme & Bce & Bpo & Bmq & Bma & Bal & Bst & Bla & Bbr & Bcy & Tsa & Tvu & Lpl & Lme & Spa & Nas & Tch \\
\hline Evu & 95 & & & & & & & & & & & & & & & & & & & & & \\
\hline Sau & 50 & 45 & & & & & & & & & & & & & & & & & & & & \\
\hline Shy & 58 & 53 & 94 & & & & & & & & & & & & & & & & & & & \\
\hline Bsu & 45 & 40 & 84 & 78 & & & & & & & & & & & & & & & & & & \\
\hline Bme & 45 & 40 & 80 & 74 & 80 & & & & & & & & & & & & & & & & & \\
\hline Bce & 50 & 45 & 85 & 79 & 90 & 90 & & & & & & & & & & & & & & & & \\
\hline Bpo & 45 & 40 & 79 & 72 & 79 & 65 & 75 & & & & & & & & & & & & & & & \\
\hline $\mathrm{Bmq}$ & 40 & 35 & 65 & 58 & 75 & 65 & 75 & 85 & & & & & & & & & & & & & & \\
\hline Bma & 47 & 42 & 89 & 82 & 83 & 74 & 79 & 89 & 79 & & & & & & & & & & & & & \\
\hline $\mathrm{Bal}$ & 45 & 40 & 84 & 78 & 74 & 65 & 70 & 84 & 70 & 94 & & & & & & & & & & & & \\
\hline Bst & 50 & 45 & 85 & 79 & 85 & 95 & 95 & 70 & 70 & 79 & 70 & & & & & & & & & & & \\
\hline Bla & 50 & 45 & 70 & 68 & 75 & 65 & 70 & 70 & 70 & 79 & 70 & 70 & & & & & & & & & & \\
\hline Bbr & 45 & 40 & 74 & 67 & 79 & 65 & 70 & 74 & 70 & 83 & 74 & 70 & 80 & & & & & & & & & \\
\hline Bcy & 35 & 30 & 65 & 58 & 70 & 75 & 70 & 60 & 55 & 68 & 60 & 75 & 60 & 60 & & & & & & & & \\
\hline Tsa & 40 & 45 & 70 & 63 & 75 & 75 & 75 & 65 & 60 & 74 & 65 & 80 & 65 & 65 & 75 & & & & & & & \\
\hline Tvu & 45 & 40 & 75 & 68 & 80 & 80 & 80 & 70 & 65 & 79 & 70 & 85 & 70 & 70 & 80 & 90 & & & & & & \\
\hline Lpl & 63 & 58 & 47 & 44 & 47 & 47 & 47 & 53 & 53 & 56 & 47 & 47 & 53 & 47 & 42 & 42 & 47 & & & & & \\
\hline Lme & 50 & 45 & 45 & 37 & 45 & 45 & 45 & 45 & 40 & 47 & 40 & 45 & 40 & 45 & 50 & 40 & 45 & 72 & & & & \\
\hline Spa & 44 & 39 & 39 & 33 & 39 & 39 & 39 & 44 & 44 & 47 & 44 & 39 & 39 & 39 & 50 & 33 & 39 & 50 & 41 & & & \\
\hline Nas & 40 & 45 & 35 & 32 & 35 & 35 & 35 & 35 & 30 & 37 & 30 & 35 & 45 & 35 & 45 & 40 & 35 & 39 & 47 & 65 & & \\
\hline Tch & 47 & 42 & 47 & 42 & 47 & 47 & 47 & 53 & 47 & 56 & 47 & 47 & 47 & 47 & 47 & 42 & 47 & 53 & 39 & 76 & 61 & \\
\hline Tme & 47 & 42 & 47 & 42 & 47 & 47 & 47 & 47 & 42 & 50 & 42 & 47 & 47 & 47 & 47 & 42 & 47 & 47 & 39 & 71 & 61 & 94 \\
\hline
\end{tabular}

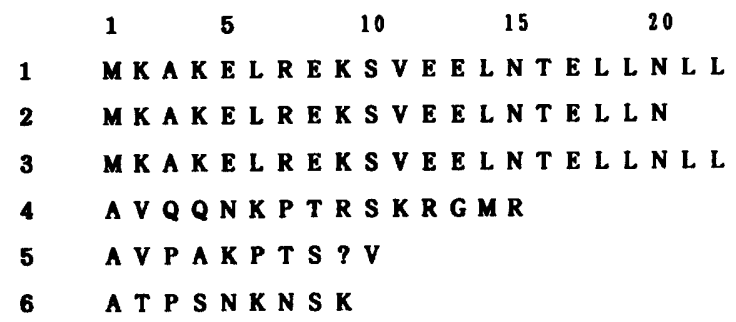

Fig. 2. Primary structures of $\mathrm{N}$-termini of the $\mathrm{L} 29$ proteins from Escherichia coli K12 (line 1), Escherichia fergusonii JCM 5897 (line 2) and Escherichia vulneris JCM $1688^{\top}$ (line 3), or the L32 proteins from Escherichia coli K12 (line 4), Lactobacillus plantarum JCM $1149^{\top}$ (line 5) and Leuconostoc mesenteroides JCM $6124^{\top}$ (line 6). The data for the L29 or L32 protein from $E$. coli are from Bitar (1974) and Wittmann-Liebold et al. (1975), respectively. JP accession numbers are as follows: Efe (JP0070), Evu (JP0071), Lpl (JP0072), Lme (JP0073).

Escherichia bermannii, E. vulneris and E. fergusonii were reported to be new species in the genus Escherichia, mainly on the basis of DNA relatedness or biochemical aspects (Brenner et al., 1982a, b; Farmer et al., 1985). Amino acid sequence data of L30 proteins of these species, together with that of Escherichia coli, are shown in Fig. 1. These species revealed a high level of homology (SAS $\geqslant 95 \%$ ) for every combination of strains (Table 1). Complete homology was detected between E. coli, E. hermannii and E. fergusonii. In contrast, a low level of homology (SAS $50 \%$ ) was detected between E. coli and S. aureus (Table 2). Amino acid sequence analysis of another ribosomal protein L29, from three Escherichia species demonstrated a close relatedness (SAS 100\%) among the species examined (Fig. 2), leading to a conclusion similar to that obtained from the L30 analysis. Thus, within a single genus of eubacteria, the homology level of amino acid sequences in L 30 proteins is very high. This has previously been reported for actinomycetes, in which a homology level higher than $85 \%$ was usually detected within a single genus (Ochi \& Miyadoh, 1992; Ochi et al., $1993 \mathrm{a}, \mathrm{b})$.

\section{(2) Genus Bacillus}

The eleven species of the genus Bacillus which we examined revealed considerable diversity in amino acid sequences of their L30 proteins (Fig. 1). The homology level was as low as $55 \%$ between $B$. cyclobeptanicus and $B$. macquariensis, while it was as high as $95 \%$ between $B$. cereus and $B$. stearothermophilus (Table 2). On the basis of these SAS values we compiled a dendrogram (Fig. 3). The tree 


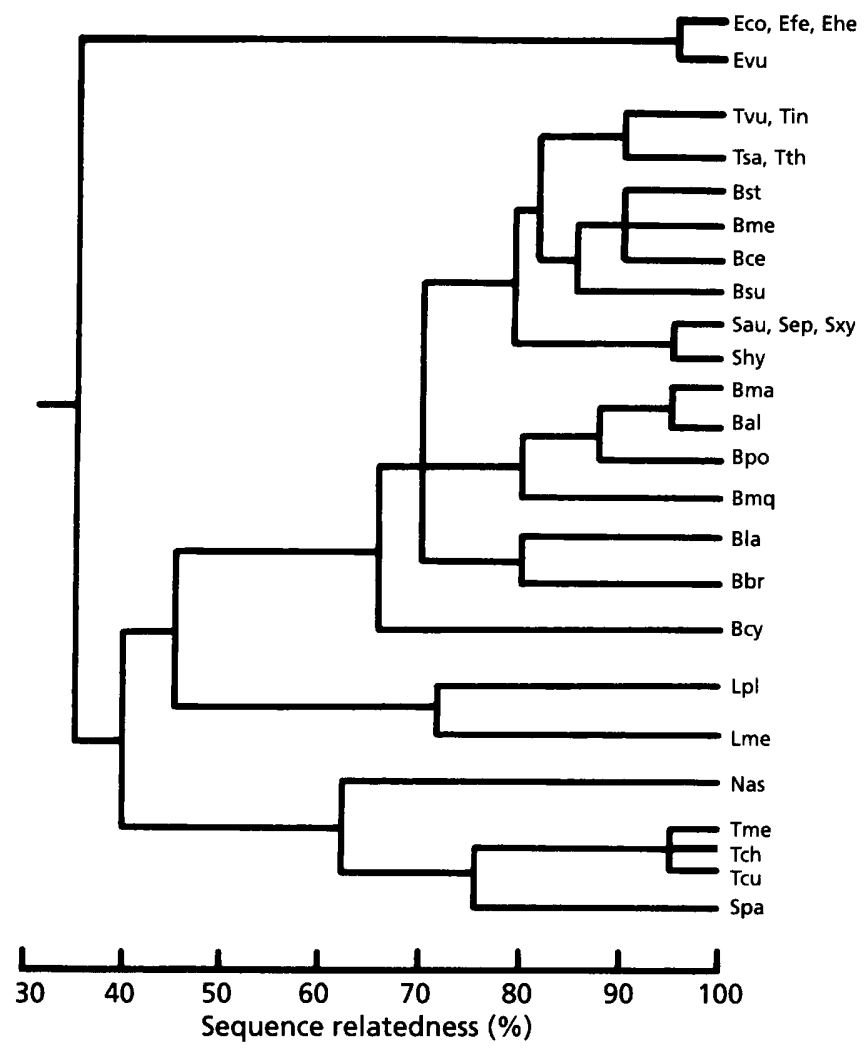

Fig. 3. Clustering of $L 30$ or AT-L30 protein SAS values. The dendrogram was constructed using the data in Fig. 1. The abbreviation used for each organism is presented in Table 1.

was constructed by using a phylogenetic algorithm to minimize the fluctuation. In the tree, eleven Bacillus species were divided into four major clusters; the first cluster included B. subtilis, B. stearothermophilus, B. cereus and $B$. megaterium; the second cluster included $B$. alve $i, B$. macerans, $B$. polymyxa and $B$. macquariensis; the third cluster included B. brevis and B. laterosporus; and the fourth branch had a single representative $B$. cyclobeptanicus. Strikingly, this classification was entirely consistent with the results from $16 \mathrm{~S}$ rRNA sequence analysis conducted by Rössler et al. (1991). Within each of three multi-species clusters, greater than $80 \%$ sequence homology existed between all combinations of members, whereas between the four clusters less than $70 \%$ sequence homology was found. Surprisingly, members of the first cluster including B. subtilis shared more sequence homology with the genus Stapbylococcus than any of the other Bacillus clusters (Fig. 3 ). The result would support the need for reclassification of Bacillus at the genus level. Bacillus cycloheptanicus was most distantly related to other members of Bacillus.

\section{(3) Genus Thermoactinomyces}

The Approved List of Bacterial Names (Skerman et al., 1980) includes five species of the genus Thermoactinomyces, and Bergey's Manual of Systematic Bacteriology (Lacey \& Cross, 1989) recognizes seven, including Thermo- actinomyces vulgaris, $T$. intermedius, $T$. sacchari and $T$. thalpopbilus. These four species are all thermophilic, growing at $30-60^{\circ} \mathrm{C}$. Endospores formed singly on both aerial and substrate mycelium are either sessile ( $T$. thalpophilus) or on unbranched sporophores ( $T$. vulgaris, $T$. sacchari). The endospores of $T$. intermedius are sessile or on short sporophores. Highly homologous sequences (Fig. 1) were found among the four species examined (SAS 90-100\%, Table 2), indicating that the genus Thermoactinomyces is phylogenetically homogeneous. AT-L30 proteins (homologous to the E. coli $\mathrm{L} 30$ protein) from Streptomyces parvulus, Nocardia asteroides and members of the genus Thermomonospora were also analysed as representatives of other actinomycete genera. The sequences for Thermoactinomyces species exhibited a higher level of homology to those of eubacteria than to those of actinomycetes (Fig. 1). It is especially noteworthy that, as shown in the dendrogram, the genus Thermoactinomyces is closely related to the members of the Bacillus subtilis cluster, the highest homology being with Bacillus stearothermophilus (SAS $85 \%$, Fig. 3). Thermoactinomyces strains can resemble members of the actinomycete genus Thermomonospora in their morphology but with these latter organisms a distant phylogenetic relatedness was revealed (Fig. 3).

\section{(4) Genera Lactobacillus and Leuconostoc}

Lactobacillus plantarum and Leuconostoc mesenteroides, members of the lactic bacteria, were placed at a distant phylogenetic position not only from Escherichia coli but also from Bacillus species (Fig. 3). A distant relatedness between $E$. coli and $L$. plantarum or $L$. mesenteroides was also supported by the low level of homology in another ribosomal protein, L32 (Fig. 2).

\section{Amino acid sequences characteristic for each genus}

In addition to a simple comparison of the homology of amino acid sequences, it was possible to pinpoint amino acids, located at specific positions, which characterize each genus. Such amino acids are boxed in Fig. 1. The results can be summarized as follows. (1) In eubacteria, including the genus Thermoactinomyces, position 16 or 17 is characterized by proline, while in actinomycetes it is lysine. (2) Position 15 is characterized by arginine in eubacteria. (3) In actinomycetes, positions 5, 18 and 20 are characterized by lysine, asparagine and aspartic acid, respectively. Also, a deletion at position 2 appears to be a characteristic for actinomycetes. (4) Positions 7 (threonine) and 11 (serine) were invariable throughout the bacteria examined. (5) It is especially noteworthy that position 12 appears to reflect the classification at the genus level, as seen from alanine for the genus Escherichia, valine for the genus Stapbylococcus, methionine for the genus Thermoactinomyces, and lysine for the genus Thermomonospora. More than 30 members of the genus Streptomyces examined were all characterized by tyrosine at this position (Ochi \& Hiranuma, 1994). Similarly, the observed distinction among the Bacillus clusters can be further emphasized. For example, the members of the 
genus Bacillus examined could be divided into three groups from the amino acid at position 12: a 'valine group' including B. subtilis, B. megaterium, B. cereus and $B$. stearothermophilus; a 'leucine group' including $B$. alvei, $B$. polymyxa, B. macquariensis, B. macerans, $B$. brevis and $B$. laterosporus; and a 'proline group' represented by $B$. cyclobeptanicus as a single species (Fig. 1). It is striking that this grouping is consistent with the grouping based on the protein L30 sequence homology (Fig. 3), with the exception that the B. subtilis cluster and the B. brevis cluster were not discriminated.

Thus, together with comparison by sequence homology, position 12 can be used as a good standard for differentiation of bacteria at the genus level. For example, since methionine has not been found in any L30 or AT-L30 proteins examined so far, its presence at position 12 should be a characteristic typical for the genus Thermoactinomyces.

It was also noteworthy that in members of the $B$. alvei cluster including $B$. macerans, B. macquariensis and $B$. polymyxa a large fraction (15-70\%) of the L30 proteins retained methionine residues in their $\mathrm{N}$-termini.

\section{DISCUSSION}

This paper is a further expansion of our new approach to the classification of micro-organisms and raises an intriguing possibility that L30 protein analysis may be effective for the taxonomy of not only actinomycetes but also other eubacteria. Despite the similar electrophoretic properties of L30 proteins, eubacteria still exhibited extensive variability in amino acid sequence of the proteins. In the present study a close phylogenetic relationship between the genus Thermoactinomyces and the B. subtilis cluster within the genus Bacillus was demonstrated. Thus, despite the entirely different taxonomic approaches used, we reached a similar conclusion to that of Stackebrandt et al. (1987): that the genus Thermoactinomyces should be classified in the family Bacillaceae and not with the actinomycetes.

In the phylogenetic tree (Fig. 3) we can see three main stems, representing Gram-positive and Gram-negative bacteria, and actinomycetes. Although actinomycetes exhibit a Gram-positive staining reaction they form a deep branch from the main stem for Gram-positive eubacteria. This view is consistent with the work of Stackebrandt \& Woese (1981) using 16S rRNA oligonucleotide cataloguing. Their work also demonstrated that the genus Nocardia, although it exhibits several eubacteria-like characters (Goodfellow \& Lechevalier, 1989), belongs to the actinomycetes (Stackebrandt \& Woese, 1981). Our results support the latter conclusion (Fig. 3).

The taxonomic status of Thermoactinomyces vulgaris and $T$. thalpopbilus has been confused at the species level: the epithet 'vulgaris' is often used in the literature to describe T. thalpophilus. These two organisms, however, could be clearly discriminated by differences in the $\mathrm{L} 30$ amino acid sequence at positions 6 and 18 (Fig. 1). Since $100 \%$ homology in AT-L30 amino acid sequence has been detected in various Streptomyces species (Ochi \& Hiranuma, 1994), the homology level (100\% or not) might be used to demonstrate differentiation at the species level. Likewise, Eschericbia vulneris and S. byicus could be discriminated from $E$. coli and $S$. aureus, respectively, confirming that these are separable at the species level (Fig. 1).

It is generally believed that many kinds of ribosomal proteins, including L30 proteins, are assembled into ribosomal RNA after undergoing processing of their native forms (Srivastava \& Schlessinger, 1990). Ribosomes containing pre-16S rRNA are not biologically active: processing to mature $16 \mathrm{~S}$ rRNA molecules is obligate for competence in protein synthesis (Wireman \& Sypherd, 1974). Therefore, it is curious that there are ribosomal L30 proteins with methionine in their $\mathrm{N}$ termini. These unprocessed (or incompletely processed) L30 proteins in the ribosome fraction have been found only in the members of the $B$. alvei cluster of the genus Bacillus among the bacteria examined so far. This phenomenon may thus be a characteristic typical for this cluster.

\section{ACKNOWLEDGEMENT}

This study was partly supported by a grant from Basic Research Core System.

\section{REFERENCES}

Ash, C., Farrow, A. E., Wallbanks, S. \& Collins, M. D. (1991). Phylogenetic heterogeneity of the genus Bacillus revealed by comparative analysis of small-subunit-ribosomal RNA. Lett Appl Microbiol 13, 202-206.

Becker, B., Lechevalier, M. P. \& Lechevalier, H. A. (1965). Chemical composition of cell wall preparations from strains of various formgenera of aerobic actinomycetes. Appl Microbiol 13, 236-243.

Bitar, K. G. (1974). The primary structure of the ribosomal protein L29 from Escherichia coli. Biochim Biophys Acta 386, 99-106.

Brenner, D. J., Davis, B. R., Steigerwalt, A. G., Riddle, C. F., McWhorter, A. C., Allen, S. D., Farmer III, J. J., Saitoh, Y. \& Fanning, R. (1982a). Atypical biogroups of Escherichia coli found in clinical specimens and description of Escherichia bermannii sp. nov. $J$ Clin Microbiol 15, 703-713.

Brenner, D. J., McWhorter, A. C., Knutson, J. K. L. \& Steigerwalt, A. G. (1982b). Escherichia vulneris: a new species of Enterobacteriaceae associated with human wounds. J Clin Microbiol 15, 1133-1140.

Claus, D. \& Berkeley, R. C. W. (1986). Genus Bacillus. In Bergey's Manual of Systematic Bacteriology, vol. 2, pp. 1104-1139. Edited by P. H. A. Sneath, N. S. Mair, M. E. Sharpe \& J. G. Holt. Baltimore: Williams \& Wilkins.

Collins, M. D., Mackillop, G. C. \& Cross, T. (1982). Menaquinone composition of members of the genus Thermoactinomyces. FEMS Microbiol Lett 13, 151-153.

Craveri, R. \& Manachini, P. L. (1966). Base composition of DNA in Streptomyces argenteolus and Thermoactinomyces vulgaris cultivated at different temperatures. Ann Microbiol Enzimol 16, 1-3. (in Italian).

Cross, T., Davies, F. L. \& Walker, P. D. (1971). Thermoactinomyces vulgaris. I. Fine structure of the developing endospores. In Spore Research, pp. 175-187. Edited by A. N. Barker, G. W. Gould \& J. Wolf. London: Academic Press.

Dekio, S., Yamasaki, R., Jidoi, J., Hori, H. \& Osawa, S. (1984). 
Secondary structure and phylogeny of Staphylococcus and Micrococcus 5S rRNAs. J Bacteriol 159, 233-237.

Devriese, L. A., Hajek, V., Oeding, P., Meyer, S. A. \& Schleifer, K. H. (1978). Stapbylococcus byicus (Sompolinsky 1953) comb. nov. and Staphylococcus byicus subsp. chromogenes subsp. nov. Int J Syst Bacteriol 28, 482-490.

Farmer III, J. J., Fanning, G. R., Davis, B. R., O'Hara, C. M., Riddle, C., Hickman-Brenner, F. W., Asbury, M. A., Lowery III, V. A. \& Brenner, D. J. (1985). Escherichia fergusonii and Enterobacter taylorae, two new species of Enterobacteriaceae isolated from clinical specimens. J Clin Microbiol 21, 77-81.

Farrow, J. A. E., Ash, C., Wallbanks, S. \& Collins, M. D. (1992). Phylogenetic analysis of the genera Planococcus, Marinococcus and Sporosarcina and their relationships to members of the genus Bacillus. FEMS Microbiol Lett 93, 167-172.

Fritzsche, H. (1967). Infra-red studies of deoxyribonucleic acids, their constituents and analogues. II. Deoxyribonucleic acids with different base compositions. Biopolymers 5, 863-870.

Goodfellow, M. \& Lechevalier, M. P. (1989). Genus Nocardia. In Bergey's Manual of Systematic Bacteriology, vol. 4, pp. 2350-2361. Edited by S. T. Williams \& J. G. Holt. Baltimore: Williams and Wilkins.

Gordon, R. E. (1981). One hundred and seven years of the genus Bacillus. In The Aerobic Endospore-forming Bacteria: Classification and Identification, pp. 1-15. Edited by R. C. W. Berkeley \& M. Goodfellow. London: Academic Press.

Kaltschmidt, E. \& Wittmann, H. G. (1970). Ribosomal proteins. VII. Two-dimensional polyacrylamide gel electrophoresis for finger-printing of ribosomal proteins. Anal Biochem 36, 401-412.

Kimura, M. (1984). Proteins of the Bacillus stearothermophilus ribosome. J Biol Chem 259, 1051-1055.

Lacey, J. (1971). Thermoactinomyces sacchari $\mathrm{sp}$. nov., a thermophilic actinomycete causing bagassosis. J Gen Microbiol 66, 327-338.

Lacey, J. \& Cross, T. (1989). Genus Thermoactinomyces. In Bergey's Manual of Systematic Bacteriology, vol. 4, pp. 2574-2585. Edited by S. T. Williams \& J. G. Holt. Baltimore: Williams and Wilkins.

Logan, N. A. \& Berkeley, R. C. W. (1981). Classification and identification of members of the genus Bacillus using API tests. In The Alerobic Endospore-forming Bacteria: Classification and Identification, pp. 105-140. Edited by R. C. W. Berkeley \& M. Goodfellow. London: Academic Press.

Ochi, K. (1989). Heterogeneity of ribosomal proteins among Streptomyces species and its application to identification. $J$ Gen Micrabiol 135, 2635-2642.

Ochi, K. (1992a). Electrophoretic heterogeneity of ribosomal protein AT-L30 among actinomycete genera. Int J Syst Bacteriol 42, 144-150.

Ochi, K. (1992b). Polyacrylamide gel electrophoresis analysis of ribosomal protein: a new approach for actinomycete taxonomy. Gene 115, 261-265.

Ochi, K. \& Hiranuma, H. (1994). A taxonomic review of the genera Kitasatosporia and Streptoverticillium by analysis of ribosomal protein AT-I.30. Int J Syst Bacteriol 44, 285-292.

Ochi, K. \& Miyadoh, S. (1992). Polyacrylamide gel electrophoresis analysis of ribosomal protein AT-L30 from an actinomycete genus, Streptosporangium. Int J Syst Bacteriol 42, 151-155.

Ochi, K. \& Yoshida, M. (1992). Polyacrylamide gel electrophoresis analysis of mycolate-less wall chemotype IV actinomycetes. Int $J$ Syst Bacteriol 41, 402-405.
Ochi, K., Miyadoh, S. \& Tamura, T. (1991). Polyacrylamide gel electrophoresis analysis of ribosomal protein AT-L30 as a novel approach to actinomycete taxonomy: application to the genera Actinomadura and Microtetraspora. Int J Syst Bacteriol 41, 234-239.

Ochi, K., Haraguchi, K. \& Miyadoh, S. (1993a). A taxonomic review of the genus Microbispora by analysis of ribosomal protein AT-L30. Int J Syst Bacteriol 43, 58-62.

Ochi, K., Satoh, E. \& Shima, J. (1993b). Amino acid sequence analysis of ribosomal protein AT-L30 from Streptosporangium corrugatum and Kibdelosporangium aridum. Syst Appl Microbiol 16, 13-16.

Priest, F. G. (1981). DNA homology in the genus Bacillus. In The Aerobic Endospore-forming Bacteria: Classification and Identification, pp. 33-57. Edited by R. C. W. Berkeley \& M. Goodfellow. London: Academic Press.

Ritter, E. \& Wittmann-Liebold, B. (1975). The primary structure of protein L30 from Escherichia coli ribosomes. FEBS Lett 60, 153-155.

Rössler, D., Ludwig, W., Schleifer, K. H., Lin, C., McGill, T. J., Wisotzkey, J. D., Jurtshuk, P., Jr \& Fox, G. E. (1991). Phylogenetic diversity in the genus Bacillus as seen by $16 \mathrm{~S}$ rRNA sequencing studies. Syst Appl Microbiol 14, 266-269.

Schleifer, K. H. \& Kloos, W. E. (1975). Isolation and characterization of Staphylococci from human skin. I. Amended descriptions of Staphylococcus epidermidis and Staphylococcus saprophyticus and descriptions of three new species: Staphylococcus cobnii, Staphylococcus baemolyticus, and Stapbylococcus xylosus. Int J Syst Bacteriol 25, 50-61.

Skerman, V. B. D., McGowan, V. \& Sneath, P. H. A. (1980). Approved lists of bacterial names. Int J Syst Bacteriol 30, 225-420.

Srivastava, A. K. \& Schlessinger, D. (1990). rRNA processing in Escherichia coli. In The Ribosomes, pp. 426-434. Edited by W. E. Hill, A. Dahlberg, R. A. Garrett, P. B. Moore, D. Schlessinger \& J. R. Warner. Washington, DC: American Society for Microbiology.

Stackebrandt, E. \& Woese, C. R. (1981). Towards a phylogeny of the actinomycetes and related organisms. Curr Microbiol 5, 197-202.

Stackebrandt, E., Ludwig, W., Weizenegger, M., Dorn, S., McGill, T. J., Fox, G. E., Woese, C. R., Schubert, W. \& Schleifer, K.-H. (1987). Comparative $16 \mathrm{~S}$ rRNA oligonucleotide analyses and murein types of round-spore-forming bacilli and non-sporeforming relatives. J Gen Microbiol 133, 2523-2529.

Wireman, J. W. \& Sypherd, P. S. (1974). In vitro assembly of $30 \mathrm{~S}$ ribosomal particles from precursor 16S RNA of Escherichia coli. Nature 247, 552-554.

Wisotzkey, J. D., Jurtshuk, P., Jr, Fox, G. E., Deinhard, G. \& Poralla, K. (1992). Comparative sequence analyses on the $16 \mathrm{~S}$ rRNA (rDNA) of Bacillus acidocaldarius, Bacillus acidoterrestris, and Bacillus cyclobeptanicus and proposal for creation of a new genus, Alicyclobacillus gen. nov. Int J Syst Bacteriol 42, 263-269.

Wittmann-Liebold, B., Greuer, B. \& Pannenbecker, R. (1975). The primary structure of protein L32 from the 50 S subunit of Escherichia coli ribosomes. Hoppe-Seyler's Z Physiol Chem 356, 1977-1979.

Wittmann-Liebold, B., Kopke, A. K. E., Arndt, E., Kromer, W., Hatakeyama, T. \& Wittmann, H. G. (1990). Sequence comparison and evolution of ribosomal proteins and their genes. In The Ribosomes, pp. 598-616. Edited by W. E. Hill, A. Dahlberg, R. A. Garrett, P. B. Moore, D. Schlessinger \& J. R. Warner. Washington, DC: American Society for Microbiology.

Received 23 August 1993; revised 1 March 1994; accepted 11 March 1994. 